\title{
アニオンリビング重合法による分子量の揃った シリル基を含むポリマーの合成
}

\author{
平 尾 明*.中 浜 精 -* \\ Synthesis of Functional Silyl Group Containing Polymers with \\ Controllable Molecular Weights and Narrow Molecular Weight \\ Distributions by Means of Anionic Living Polymerization.
}

Akira $\mathrm{H}_{\mathrm{IRAO}} *$ and Seiichi $\mathrm{N}_{\text {AKahama }}$ *

\begin{abstract}
Anionic living polymerizations of monomers with functional silyl groups are reviewed. The monomers include styrenes and 1, 3-butadiene derivatives containing Si-OR, Si-NEt ${ }_{2}, \mathrm{Si}-\mathrm{H}, \mathrm{Si}-\mathrm{O}-\mathrm{SiMe}_{3}, \mathrm{Si}-\mathrm{SiMe} \mathrm{S}_{3}, \mathrm{Si}-\mathrm{CH}_{2}-\mathrm{CH}$ $=\mathrm{CH}_{2}$, and $\mathrm{Si}-\mathrm{CH}=\mathrm{CH}_{2}$. The polymerizations of these monomers with anionic initiators such as butyllithium, alkali-metal naphthalenides and oligo ( $\alpha$-methylstyryl) dialkali-metal salts, always proceed without chain transfer and termination reactions to afford stable living polymers, although the limited conditions are required in some cases. The polymers with controllable molecular weights and narrow molecular weight distributions $\left(\overline{\mathbf{M}}_{\mathrm{w}} / \overline{\mathbf{M}}_{\mathrm{n}} \leq 1.1\right)$ are obtained in all cases described here. Synthesis of new types of block copolymers with styrene, isoprene with these monomers are also discussed.
\end{abstract}

\section{1. はじめに}

高分子化合物の諸性質が，その分子量に大きく依存し ていることは良く知られている。したがって高分子化合 物の分子量制御を可能にし，かつ分子量を揃える方法を 開発することは, 材料の機能をより精緻に発揮させ，また 材料のある種の極限性質を見極める上で極めて重要な役 割を果たすと思われる。しかしながら重合反応では一般 に分子量の制御は難しく, 得られる高分子化合物は広い 分子量分布を持つ混合物であり，それらの分離や精製は 困難である。

1956 年にSzwarcにより見出されたスチレンのアニオ ンリビング重合法は, その重合反応において開始と生長 反応だけからなり，連鎖移動や停止反応がないため, 設 計通りの分子量を持ち分子量分布の狭いポリスチレンの 合成を可能にした点で優れた方法と言えよう1)。以来膨

\section{* 東京工業大学工学部高分子工学科}

* Department of Polymer Chemistry, Faculty of Engineering, Tokyo Institute of Technology
大な研究例が報告されているが, 主にリビングポリマー の活性末端の構造や反応性，あるいはブロック共重合体 の合成やその物性研究に集中しており，この方法に適用 可能なモノマー群は，わずかな例外を除き，スチレンや 共役ジエン類の炭化水素系モノマーに限定されてい る2)。その理由をスチレンのリビングポリマーを例にと り考察してみる。

スチレンは比較的アニオン重合がしにくいモノマーで あり，ブチルリチウム $(\mathrm{BuLi})$ や $\mathrm{Na}$-ナフタレン錯体で代 表される求核性の非常に強い試薬が開始剤として要求さ れる3)。そして下式に示すように，まず開始反応，つい

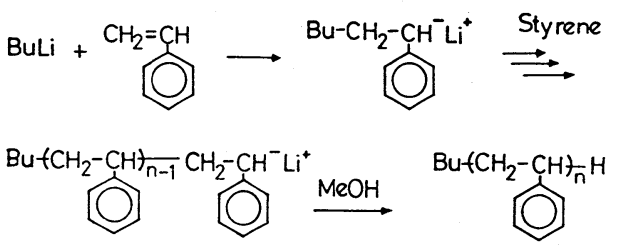

で生長反応により重合は進行し，生長鎖末端はベンジル 型のカルバニオンになるが，依然として高い反応性を保 持している。この重合系の特徵として, 系中の酸素や水 を充分除き溶媒やモノマーが精製してあれば，生長鎖末 
端アニオンは長時間安定に存在できる。そのためこの系 では求核性の高いカルバニオンが常時存在していること になり，通常の官能基があれば移動や停止反応がすぐに 起きることは容易に想像される。特に重合反応において は生長反応として生長末端アニオンがスチレンの二重結 合へ付加する反応が数百一数万回繰り返されるが, その 間わずかでも副反応が起きると分子量やその分布に深刻 な影響がでるので相当に不活性な官能基でもその存在が 問題になってくる。このようなことから, カルバニオン に対して不活性と考えられる炭化水素系モノマーにこの 方法が限定されていたと推測される。

Szwarcの報告以後類似の例を除けば，開環重合にお いていくつかのリビングポリマーが見出されている。特 に最近になり, 新しい型の開始剤を用いた系 ${ }^{4,5)}$, ラジ カル ${ }^{6)}$ やカチオン7), さらに配位重合 ${ }^{8,9}$ においてもリビ ング重合やそれに近い挙動を示す例が報告され始め, 徐々にではあるが適用可能なモノマーの種類が広がりつ つある。しかし実際に分子量の制御が広範囲 $\left(10^{3} \sim 10^{7}\right)$ にわたって可能であり，その範囲内で分子量が揃ってい ること, さらにカルバニオンのような反応性の非常に高 い活性末端が長時間安定に存在できる点を考え合わせる と, 現在でもスチレンや共役ジエン類のアニオンリビン グ重合が最も優れた方法であろう ${ }^{10)}$ 。従って著者らは, もしこのアニオンリビング重合法が広範囲な官能基を持 つモノマー類まで応用できれば，機能性材料の分子設計 を進める上で, 非常に有力な手段になると考えている。

以上の背景を基に, 我々は数年来官能基含スチレン類 を中心としたモノマー群におけるアニオンリビング重合 の適用条件を検討している。その結果, 反応系の工夫的 や注意深く条件を選べば保護基の導入の可能な例も見つ かり，従来難しいとされていた官能基を持ついくつかの リビングポリマーの合成に成功し, 前回報告した ${ }^{12)}$ 。

最近になり，有用な注目すべきケイ素原子を含む官能 基を持つスチレンや1,3-ブタジエン類もアニオンリビ ング重合が可能な例が見出されたので，今回はそれらに ついて述べてみたい。具体的には，アルコキシシリル基, アミノシリル基, ヒドロシリル基, アリルシリル基, ビ ニルシリル基, さらにシロキサンやジシラン結合を含む モノマー類である。ケイ素原子を含む高分子が新しい機 能材料として注目され, 実用化の可能性に向かって基盤 を固めつつある現在 ${ }^{13)}$, ここで報告するポリマー類もそ の一翼をになうと予想される。特に分子設計を考えた場 合, リビングポリマーの存在は有力な手段となりうるだ ろう。さらにシリル基の反応性を考慮すると，ケイ素化 学で報告されている多彩な反応をポリマー上で展開する

ことが可能であることより, 一層広範囲な機能材料の提 供が期待できる。

\section{2. シリル基含モノマー類のアニオンリビング} 重合

2.1. 4-(アルコキシシリル)スチレン誘導体 ${ }^{14,15)}$ ア ルコキシシリル基 (Si-OR) 基は加水分解を受け易く, そ の際にシラノール $(\mathrm{Si}-\mathrm{OH})$ に変換される。シラノール基 は不安定ですぐ自己縮合しシロキサン結合 $(\mathrm{Si}-\mathrm{O}-\mathrm{Si}$ 結 合)を形成するが，無機材料や金属材料があればシロキ シ結合 $(\mathrm{Si}-\mathrm{O}$ 結合) を通して, それらの表面部分と反応, 結合することが良く知られている。アルコキシシリル基 を含む一連の化合物はこの反応性を利用して, 有機-無 機材料の界面処理剂として広く応用されている。有機化 学的にはアルコシシリル基は求核置換反応の良い脱離基 と見なされ，アルキルリチウムやグリニャール試薬によ り容易に置換反応が起きる。ここでアルキルリチウムが スチレンの良いアニオン開始剤であることを考えれば, 下記に示す 4-(アルコキシシリル) スチレン $(1)^{16)}$ のア

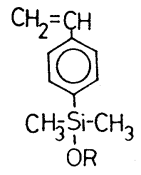

(1)

$$
\begin{aligned}
& \text { (1a) } \mathrm{R}=\mathrm{CH}_{3} \\
& \text { (1b) } \mathrm{R}=\mathrm{C}_{2} \mathrm{H}_{5} \\
& \text { (1c) } \mathrm{R}=\mathrm{i}-\mathrm{C}_{3} \mathrm{H}_{7} \\
& \text { (1d) } \mathrm{R}=\mathrm{t}-\mathrm{C}_{4} \mathrm{H}_{9}
\end{aligned}
$$

ニオン重合は困難が予想される。一方 Corey らは, ヒ ドロキシル基を ${ }^{t} \mathrm{BuMe}_{2} \mathrm{Si}$ 基で保護すると生成したシリ ルエーテルはアルキルリチウムに対して安定であること を報告している ${ }^{17)}$ 。そこで我々は下に示すモノマー ( $\mathrm{Si}-\mathrm{O}$ 結合が $1 \mathrm{~d}$ の場合と逆になっている)を合成し，アニオ

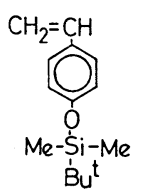

ン重合を行ったところ，このモノマーよりー78 $\mathrm{C}$ で安 定なリビングポリマーが生成することを見出した18)。こ れらの結果は, 反応性のアルコキシシリル基でもケイ素 原子近傍のかさ高さや低温 $\left(-78^{\circ} \mathrm{C}\right)$ にすれば, カルバニ オンとの共存が可能であることを示している。そこでこ れらの知見に基づき，1d 合成しアニオン重合の可能 性を調べた。

$1 \mathrm{~d}$ に K-ナフタレン錯体を加えると反応溶液は瞬時 に赤色に変わり, その色はー $78^{\circ} \mathrm{C}$, テトラヒドロフラン 


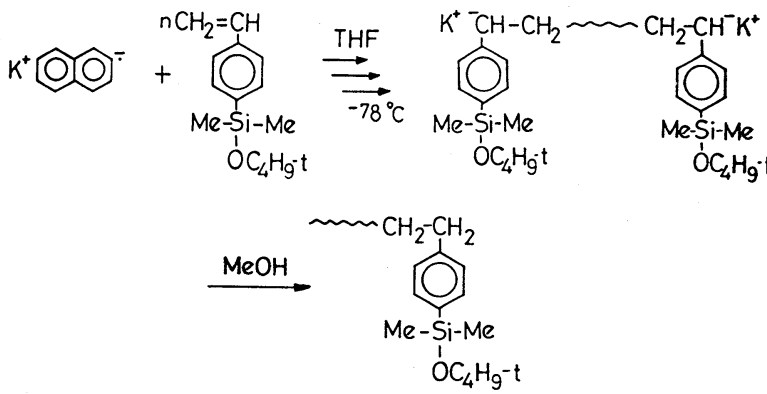

中で 24 時間後も変化しない。同じ条件でスチレンを重 合すると同様の呈色が観察され, この赤色種は生長鎖末 端のスチリルアニオンであることが良く知られている。 従って, $1 \mathrm{~d}$ の重合におけるこの現象は, 上に示すリビ ングポリマーが生成し, 末端のアニオンが安定に存在し ている強い根拠となる。系外よりメ夕ノールを加えると 消色し, 定量的にポリマーが得られる。

もし重合がリビング的に進行すれば，生成するポリ マーの数平均重合度は $[\mathrm{M}] /[\mathrm{I}]$ に比例し, さらにモ， マー単位の分子量 $(1 \mathrm{~d}$ では 234)を乗じた值が数平均分 子量 $\left(\overline{\mathbf{M}}_{\mathrm{n}}\right)$ となる(式 1$)$ 。

$$
\overline{\mathrm{M}}_{\mathrm{n}}=\frac{[\mathrm{M}]}{\mathrm{I}} \times \text { Conversion } \times 234
$$

ここで $[\mathrm{M}],[\mathrm{I}]$ は各々重合系に加えたモノマーと開始 剂のモル数であり，(式 1)を使えば得られるポリマーの 分子量が計算でき, $[\mathrm{M}] /[\mathrm{I}]$ を変えれば任意の分子量 を持つポリマーが合成可能である。実際に得られたポリ マーの分子量の実測值と (式 1)よりの計算值が一致すれ ば,リビング重合の極めて強い証拠となる。

$1 \mathrm{~d}$ の重合では $\overline{\mathrm{M}}_{\mathrm{n}}$ (計算值) $=3.0 \times 10^{4}$ であり, 得ら れたポリマーの分子量を蒸気圧法で測定した結果 $\overline{\mathbf{M}}_{\mathrm{n}}$ $($ 実測值 $)=2.9 \times 10^{4}$ となり, 実験誤差内で良く一致し た。また GPC 溶出曲線より分子量分布を調べると, 図

(a)

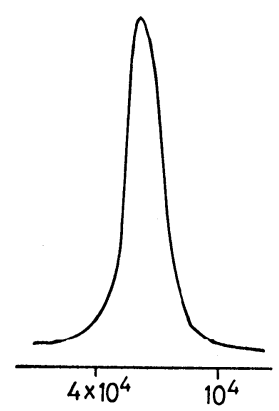

(b)

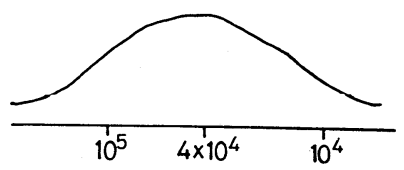

Fig. 1 Gel permeation chromatograms of poly $1 \mathrm{~d}$ (left) with an anionic initiator (a) and polystyrene (right) by a radical initiator (b) .
1 より分布が非常に狭いことが明らかである。曲線より， $\overline{\mathrm{M}}_{\mathrm{w}}$ と $\overline{\mathrm{M}}_{\mathrm{n}}$ の比を求めると 1.05 となり, 理想的な単分散 ポリマー $\left(\overline{\mathrm{M}}_{\mathrm{w}} / \overline{\mathrm{M}}_{\mathrm{n}}=1.0\right)$ に近く, 分子量が良く揃ってい ることがわかる。参考のためにラジカル重合で得られる ポリスチレンの例を並記しておく。

系中に存在する生長鎖末端アニオンの量がわかれば, $1 \mathrm{~d}$ より生成したリビングポリマーの安定性について定 量的な議論ができる。前述したように $1 \mathrm{~d}$ を重合させる と, その溶液は生長末端アニオンに基づく特有の赤色を 呈する。そこで1-オクタノールによる比色滴定を試み, その量を求めてみる。この滴定で注意すべき点は，スチ リルアニオンが酸素や水とただちに反応するため, 滴定 は完全に無水の状態で不活性ガス雲囲気下, または高真 空下 $\left(10^{-6} \mathrm{mmHg}\right)$ で行う必要がある。実際に重合終了後, 既知濃度の1-オクタノールの無水テトラヒドロフラン 溶液を加えていくと系の色は徐々にうすくなっていき, 存在するカルバニオンと当量のオクタノールを加えた時 点で完全に消色する。加えたオクタノールより生長末端 アニオンの量を求めると, 用いた開始剤の量とほぼ一致 した。この結果は, 開始剤と当モルのポリマーが生成し その末端アニオンは, 重合終了後も完全に“生きている” ことを証明している。

また $1 \mathrm{~d}$ を重合した後, その系にスチレンを加えると， スチレンの重合が進行し定量的にブロック共重合体が得

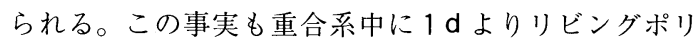
マーが生成し, 安定に存在している事実を強く支持して いる。図 2 で示す GPC 曲線より，スチレンを加える前 のポリマー (1 d の単独重合体)からスチレンを加えるこ とにより生成したブロック共重合体を示す曲線が完全に 高分子量側に移動していることが良くわかる。

次に 1 のアルキル基のかさ高さを $i-\mathrm{C}_{3} \mathrm{H}_{7}, \mathrm{C}_{2} \mathrm{H}_{5}, \mathrm{CH}_{3}$ と順に小さくした $1 \mathrm{a} \sim 1 \mathrm{c}$ を合成し，アニオン重合を

(b) (a)

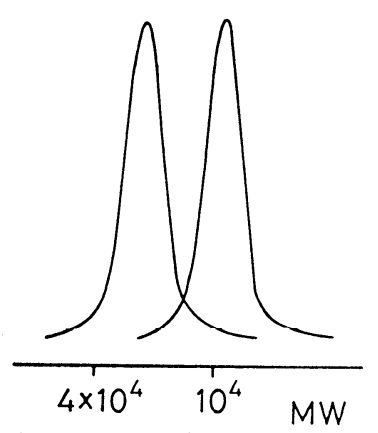

Fig. 2 Gel permeation chromatograms of poly $1 \mathrm{~d}(\mathrm{a})$ and block copolymer of $1 \mathrm{~d}$ with styrene (b). 
試みた。その結果, いずれのモノマーからもリビングポ リマーが生成しており，予想以上にアルコキシシリル基 がアニオンに対して安定であることがわかった。そこで カルバニオンに対してより不安定と想像される二および 三置換エトキシシリル基を含むスチレン 2 と 3 の重合を 行ってみると, 驚いたことにどちらからも安定なリビン

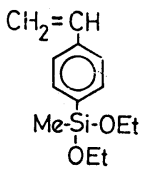

(2)

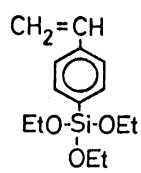

(3)
Table 1 Anionic polymerizations of 1,2 , and 3 in THF at $-78^{\circ} \mathrm{C}$ with potassium naphthalenide.

\begin{tabular}{c|c|c|c}
\hline Monomer & $\overline{\mathrm{M}}_{\mathrm{n}}$ calcd & $\overline{\mathrm{M}}_{\mathrm{n}}$ obsd & $\overline{\mathrm{M}}_{\mathrm{w}} / \overline{\mathrm{M}}_{\mathrm{n}}$ \\
\hline $1 \mathbf{a}$ & 32,000 & 33,000 & 1.07 \\
1 b & 25,000 & 27,000 & 1.10 \\
$1 \mathbf{c}$ & 14,000 & 14,000 & 1.05 \\
$1 \mathbf{c}$ & 35,000 & 33,000 & 1.06 \\
$1 \mathbf{c}$ & 100,000 & 93,000 & 1.07 \\
$1 \mathrm{~d}$ & 30,000 & 29,000 & 1.05 \\
2 & 13,000 & 13,000 & 1.07 \\
3 & 16,000 & 17,000 & 1.09 \\
\hline
\end{tabular}

グポリマーが得られた。表 1 に重合結果を示す。分子量 の実測值は計算值と良く一致し, $\overline{\mathbf{M}}_{\mathrm{w}} / \overline{\mathrm{M}}_{\mathrm{n}}$ の値はいずれ も 1.1 以内であり，分子量も良く揃っていることがわか る。1c を代表として $[\mathrm{M}] /[\mathrm{I}]$ を変えた場合, 同様の結 果が得られ分子量制御が $[\mathrm{M}] /[\mathrm{I}]$ で容易に行えること も明らかである。

1 より生じたポリマーの生長末端スチリルアニオンの 安定性は, 用いる開始剤の対カチオンや 1 のアルキル基 の種類に大きく依存する。重合条件と同様対イオンが $\mathrm{K}^{+}$の場合，1のアルキル基によらずいずれも生成した リビングポリマーは, $-78^{\circ} \mathrm{C}$ では 24 時間後でも安定に 存在している。さらに注目すべき点は, $1 \mathrm{c}$ や $1 \mathrm{~d}$ より 生成したリビングポリマーは， $30^{\circ} \mathrm{C} ， 30$ 分後も $100 \%$ 活性を保持していることである。それに対して $\mathrm{Li}^{+}$の場 合, $1 \mathrm{a}\left(\mathrm{R}=\mathrm{CH}_{3}\right)$ では, $-78^{\circ} \mathrm{C}, 30$ 分後で既に $70 \%$ が 失活している。 $1 \mathrm{~d}\left(\mathrm{R}=t-\mathrm{C}_{4} \mathrm{H}_{9}\right)$ より得られたリビング ポリマーは, この温度では 24 時間後も安定である。し かし $30^{\circ} \mathrm{C}$ にする徐々に失活しており，1dの場合で も活性末端の量は半分に減少している。これらの結果は, 1 のアニオン重合において, 開始剤の選択や反応系の重
合条件設計に注意が必要であることを意味している。

以上，アルコキシシリル基はアニオンリビング重合の 条件でも予想以上に安定でありカルバニオンとの共存が できる。そして，1，2，3のいずれからも安定なリビン グポリマーが生成でき，分子量の良く揃った設計通りの 分子量を持つポリマーを得ることができた。しかし前述 したように，アルコキシシリル基はアルキルリチウムや さらに求核性の弱いグリニャール試薬からも容易に求核 攻撃を受けることは確かめられており，また 1 から生成 したリビングポリマーの安定性が対カチオンやアルコキ シ基に著しく依存していることを考えれば，1～3のリ ビング重合の成功は，微妙なバランスの上に成立してい ることは明らかである。従って類似のモノマーにアニオ ン重合を適用する場合, 条件の選択は今後とも注意深く 行う必要がある。

2. 2. 2-(トリアルコキシシリル)-1,3-ブタジエン誘導 体 ${ }^{19,20)}$ 前節でアルコキシシリル基を含むスチレン誘 導体がリビングポリマーを生成することを述べた。その 結果より，求核試剤に極めて不安定と考えられていたア ルコキシシリル基がスチリルアニオンとは条件を選べ ば，安定に共存できることがわかった。緒言で述べたよ うに炭化水素系共役ジエンである 1,3-ブタジエンやイ ソプレン (2-メチル-1,3-ブタジエン)は, スチレン同様 リビング重合が可能である。ここでは，アルコキシシリ ル基を 2 位に導入した 1,3-ブタジエンのアニオンリビ ング重合の可能性を述べる。また共役ジエンより得られ るポリマーの物性は，一般にそのミクロ構造に著しく依 存していることが知られており，得られるポリマーのミ クロ構造も興味がある。

まず下記に示す 2-(トリイソプロポキシシリル) - 1,3ブタジエン $4 \mathrm{~b}$ を選び，1の場合と同等の重合系に適 用してみた。4 については佐藤ら ${ }^{21)}$ により合成経路が確 立しており，日産化学より市販されている。<smiles>C=CC(=C)[Sn](C)(C)C</smiles>

(4) (4a) $\mathrm{R}=\mathrm{CH}_{3}$

(4b) $\mathrm{R}=\mathrm{i}-\mathrm{C}_{3} \mathrm{H}_{7}$
$4 \mathrm{~b}$ を, $-78^{\circ} \mathrm{C}$, テトラヒドロフラン中で Oligo ( $\alpha$-methylstyryl) dipotassiumによりアニオン重合を行 うと, 重合系はブタジエンの場合と同様に黄褐色となり, その色は重合中変化はない。系外よりメ夕ノールを加え るとただちにその色は消え，粘稠なポリマーが定量的に 得られる。ポリマーの分子量， $\overline{\mathrm{M}}_{\mathrm{w}} / \overline{\mathrm{M}}_{\mathrm{n}}$ を表 2 に示す。 
Table 2 Anionic polymerization of 4 in THF at $-78^{\circ} \mathrm{C}$ with oligo ( $\alpha$-methylstyryl) dipotassium.

\begin{tabular}{c|c|c|c}
\hline Monomer & $\overline{\mathrm{M}}_{\mathrm{n}}$ calcd & $\overline{\mathrm{M}}_{\mathrm{n}}$ obsd & $\overline{\mathrm{M}}_{\mathrm{w}} / \overline{\mathrm{M}}_{\mathrm{n}}$ \\
\hline $4 \mathbf{a}$ & 14,000 & 14,000 & 1.09 \\
$4 \mathrm{~b}$ & 10,000 & 10,000 & 1.11 \\
$4 \mathrm{~b}$ & 21,000 & 19,000 & 1.10 \\
$4 \mathbf{b}$ & 36,000 & 31,000 & 1.11 \\
\hline
\end{tabular}

$[\mathrm{M}] /[\mathrm{I}]$ より算出した予想分子量 $\left(\overline{\mathbf{M}}_{\mathrm{n}}\right.$ calcd $)$ は，実 測值 $\left(\overline{\mathbf{M}}_{\mathrm{n}}\right.$ obsd) と良く一致している。GPC 測定より分子 量分布は狭く, $\overline{\mathrm{M}}_{\mathrm{w}} / \overline{\mathrm{M}}_{\mathrm{n}}$ も1.1 前後と分子量が良く揃っ たポリマーが得られている。この結果 $4 \mathrm{~b}$ の重合は, 1,3-ブタジエンと同様リビング的に進行しており, $(i-\mathrm{PrO}){ }_{3} \mathrm{Si}$ 基は生長鎖末端のカルバニオンと共存し, 重合中にその攻撃を受けていない。

ところで 4 b は分子内に二重結合が 2 つ存在している ため, ポリマーのミクロ構造は少なくとも下記に示す 4 種の可能性が考えられる。

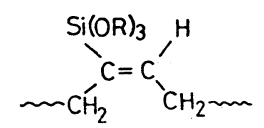

$1,4-E$

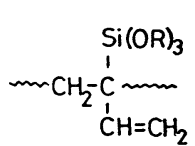

1.2-<smiles>[R19][Sn]([O-])(O)/C(=C\CC)CC</smiles>

$1,4-Z$

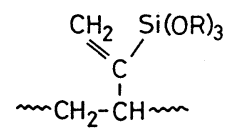

$3,4-$
実際に得られたポリマーの ${ }^{1} \mathrm{H},{ }^{13} \mathrm{C},{ }^{29} \mathrm{Si}$ の各種 $\mathrm{NMR}$, また別に合成したモデル化合物のスペクトルとの対比よ り，ポリマー構造はすべて $1,4-E$ 構造であることがわ かった。従って重合はこの条件下, 完全に位置, および 立体特異的に進行している。アニオン重合では, 1,3-ブ タジエン，イソプレンとも同条件で得られたポリマーの ミクロ構造は上記の混合物であり, 良く知られている炭 化水素溶媒中，アルキルリチウムによる立体規制を目的 とした重合でも $1,4-Z$ 構造は $90 \%$ 前後であり, 4 b の 重合挙動は極めて特異な注目すべき結果となった。特に テトラヒドロフランのような極性溶媒中, 対カチオンが $\mathrm{Li}^{+}$のみならず, $\mathrm{Na}^{+}$や $\mathrm{K}^{+}$でも位置, 立体とも完全に 特異的に進行していることは従来全く報告されておら ず，重合機構を考える上でも非常に興味深い。

2 位が $(\mathrm{MeO})_{3} \mathrm{Si}$ 基で置換された $4 \mathrm{a}$ についてもリビン グポリマーが得られ，そのミクロ構造は $100 \% 1,4$ で
あった。 NMR による立体構造解析より,この場合は $E$ $: Z=7: 3$ ( $\mathrm{K}^{+}$の場合) となり, 立体特異的にはならな かった。さらにイソプロポキシ基を順次メチル基で置き 換えていくと, $\mathrm{Me}(i-\mathrm{PrO})_{2} \mathrm{Si}, \mathrm{Me}_{2}(i$-PrO $) \mathrm{Si}$, そして $\mathrm{Me}_{3} \mathrm{Si}$ になるに従い, 得られるポリマーの位置特異性も なくなり，1,2 構造が増加していく。同時に得られたポ リマーの分子量分布はいずれも広く, 分子量の実測值と 予想值の間に違いが見られることから，重合系のリビン グ性も保てなくなっているようである。一般に求核試薬 に対する反応性は, $\mathrm{Si}(\mathrm{OPr}-i)_{3}>\mathrm{Si}(\mathrm{OPr}-i){ }_{2} \mathrm{Me}>\mathrm{SiMe}_{3}$ の順で減少し，また2.1. で述べたスチレン誘導体の結 果から考えると, アニオン開始剂や活性末端のカルバニ オンによるアルコキシシリル基への攻撃では説明が難し いように思う。原因については現在の所検討中である。 類似の系として，最近 Weber らにより，2-トリエチル シリル-1,3-ブタジエンのアニオン重合で, ヘキサン中, ブチルリチウムで重合すると $1,4-E$ 構造のみのポリ マーが得られたと報告されている22)。得られたポリマー の分子量分布は $\overline{\mathrm{M}}_{\mathrm{w}} / \overline{\mathrm{M}}_{\mathrm{n}}$ の值が1.3〜1.6となっており, リビング性を議論しているが疑わしい。

最後にアニオン重合で得られた poly 4 は，その $1,4-$ $E$ 構造を反映して, ガラス転移点 $(\mathrm{Tg})$ は $-35 \sim-37^{\circ} \mathrm{C}$ と 低く, ゴム材料としての用途が思い浮かぶ。従来の合成 ゴムに比べ, 分子中に加水分解可能な $\mathrm{Si}(\mathrm{OR})_{3}$ 基を持っ ているため, $\mathrm{S}_{8}$ による加硫工程なしでも分子間架橋で き, また加水分解で生じたシラノールより無機材料との 結合も考えられる。もちろん，そのリビング性を生かし てスチレンやジエン類との構造の規制されたブロック共 重合体の合成も可能であり，アルコキシシリル基の反応 性を考え合わせると興味ある材料が提供できよう。

2.3. その他の反応性シリル基を含むスチレン誘導体 ここでは，アルコキシシリル基以外のシリル基を有する モノマーでリビング重合が得られている例について述べ る。現在までに報告されているそのようなモノマーは少 数で, 次に示すスチレン誘導体に限られている。

5 からリビングポリマーが生成することは, トリメ チルシリル基の安定性を考えれば容易に推定できよう。 実際, 山崎ら ${ }^{23)}$, Rempp ら ${ }^{24)} に よ り 5$ のアニオンリビン グ重合が報告さている。

一方 6〜12 のスチレン誘導体中にふくまれている各シ リル基は, 興味深い反応特性や光化学的挙動が期待でき ることより，分子量の揃ったそれらのポリマーは機能材 料としてそれぞれの特性を利用し各方面への応用が可能 であろう。しかしこれらのシリル基は構造や反応性から 考えるとカルバニオンの求核攻撃も受け易く，実際にア 


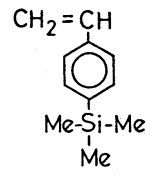

(5)

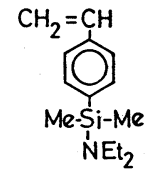

(6)

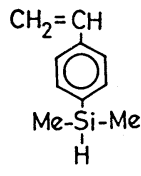

(7)

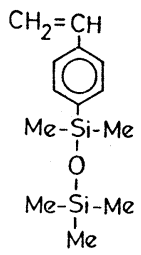

(8)

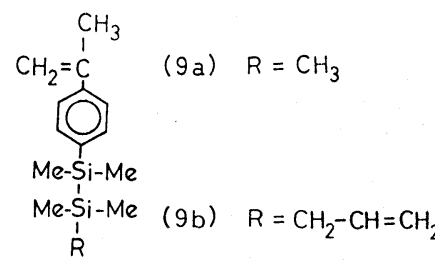

(9)

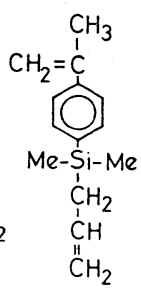

(10)

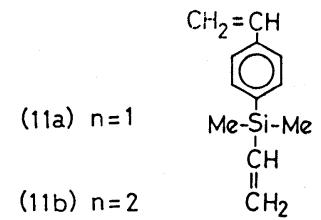

(12)

ルキルリチウムなどの有機金属試薬との反応例が多数報 告されている。従ってリビングポリマーを得るためには, それらの反応を抑え，アニオン重合を優先的に進行させ る条件を工夫する必要がある。

6 および7については, 2.1. で述べた条件でいずれも 安定なリビングポリマーを与える25,26)。ポリマーの分子 量の計算值と実測值は表 3 で示すように良い一致を示 し, 設計通りの分子量のポリマーが得られる。さらに分 子量分布は非常に狭く, $\overline{\mathrm{M}}_{\mathrm{w}} / \overline{\mathrm{M}}_{\mathrm{n}}$ の值は 1.1 以下である。 6, 7 から生成するポリマーの生長末端アニオンは一 $78^{\circ} \mathrm{C}$ で 30 分間は $\mathrm{Li}^{+}, \mathrm{Na}^{+}, \mathrm{K}^{+}$いずれの対カチオンの 場合でも安定で完全に活性を保持している。しかし長時 間経過したり, 温度を $30^{\circ} \mathrm{C}$ まで上げると徐々に失活し

Table 3 Anionic polymerizations of 6,7, and 8 in THF at $-78^{\circ} \mathrm{C}$ with oligo ( $\alpha$-methylstyryl) dipotassium.

\begin{tabular}{c|c|c|c}
\hline Monomer & $\overline{\mathrm{M}}_{\mathrm{n}}$ calcd & $\overline{\mathrm{M}}_{\mathrm{n}}$ obsd & $\overline{\mathrm{M}}_{\mathrm{w}} / \overline{\mathrm{M}}_{\mathrm{n}}$ \\
\hline 6 & 18,000 & 16,000 & 1.09 \\
7 & 14,000 & 13,000 & 1.08 \\
7 & 49,000 & 45,000 & 1.10 \\
8 & 16,000 & 14.000 & 1.13 \\
\hline
\end{tabular}

ていくのが観察される。条件により異なるので正確な此 較は難しいが1〜3のリビングポリマーとほほ同程度に 安定であると考えられる。重合を停止させて取り出した poly 6, poly 7 は比較的安定であるが, poly 6 は長時間 空気中に放置すると加水分解が徐々に起り, 分子量分布 が広がっていき最終的には不溶性のゲルとなる。

8のアニオン重合を行うと, テトラヒドロフラン中, $-78^{\circ} \mathrm{C}$ でリビングポリスチレンと同様, 特有の赤色を 示すが，この色は時間と共に薄くなり，約 1 時間後には 完全に消失する。系中のカルバニオンがシロキサン結合 を攻撃しているようで長時間両者を共存させることはで きない。ただし重合開始後数分以内に定量的にポリマー が得られ，その分子量は計算値と良く一致し，分子量も 良く揃っていることより,アニオン重合が優先して起り， 副反応による活性末端の失活はそれ以後に徐々に起って いると考えられる。

9〜11 は斉郷らにより合成され，ブチルリチウムを開 始剂として $-78^{\circ} \mathrm{C}$, テトラヒドロフラン中でアニオン重 合した例が報告されている27)。ポリマーは定量的に得ら れ，計算値と良く一致した分子量と狭い分子量分布を 持っており，重合がリビング的に進行したことを示して いる。特に9の重合に成功したことはケイ素ーケイ素結 合が生長カルバニオンと共存できることを明らかにして おり極めて興味深い。ケイ素ーケイ素結合は紫外線によ り容易に開裂すること, ケイ素含有量が高くプラズマ エッチングに対する耐久性に優れていることからこれら のポリマーはレジスト材料として開発されたものであ る。さらにリビング重合法により分子量が自由に制御で き，分子量分布の非常に狭いポリマーが合成できること はサブミクロン以下の超 LSI 用レジストとして重要な意 味を持っている。

12 は藤本らによって合成され，そのアニオン重合に おける挙動が詳細に検討されている ${ }^{28)}$ 。開始剤として, ブチルリチウム, クミルカリウム, クミルセシウムを用 い，テトラヒドロフランやジエチルエーテル中で行った 重合反応では，得られたポリマーの GPC 曲線の形より， 重合中あるいは重合後に生長末端アニオンとビニルシリ ル基との反応が起きていることが明らかになっている。 これに対して開始剤にクミルセシウムを用い，4,4-ジメ チル-1,3-メタジオキサンとジエチルエーテルの混合溶 媒中で重合すると分子量の良く揃った計算通りの分子量 を持つポリマーが定量的に得られている。このようにビ ニルシリル基を持つ 12 の重合では開始剤や溶媒の注意 深い選択や工夫が必要である。9 b，10１2 で得られた ポリマーはモノマー単位に全てビニルシランやアリルシ 
ランを有していることから, 有機ケイ素化学で展開され ているこれらシラン類の反応を利用した種々の官能基の 高分子鎖への導入も期待できる。

最後にまだアニオンリビングポリマーが生成する十分 な証拠は得られていないが，その可能性を持つ興味深い いくつかの例を示す。13 と 14 は重合性のシランカップ

$$
\begin{aligned}
\stackrel{\mathrm{C}}{\mathrm{H}_{3}} \\
\mathrm{CH}_{2}=\stackrel{\mathrm{I}}{\mathrm{I}} \\
\mathrm{O}=\mathrm{OCH}_{2} \mathrm{CH}_{2} \mathrm{CH}_{2} \mathrm{Si}(\mathrm{OMe})_{3}
\end{aligned}
$$

(13)

$$
\begin{aligned}
\mathrm{CH}_{2}= & \mathrm{CH} \\
& \mathrm{SiMe}
\end{aligned}
$$

(15)

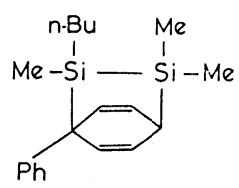

(16)
リング剂として市販されているが, これらのアニオン重 合について詳しく検討した例はない。最近，進められて いるメタクリル酸メチルのリビング重合について詳細な 研究結果を参考にして，13についてはもう一度見直し てみる必要がある ${ }^{29)}$ 。浅見らは, へキサン中, $N, N, N^{\prime}, N^{\prime}$-テトラメチルエチレンジアミン (TMEDA) の存在下でブチルリチウムを開始剤として15を重合さ せると，生長末端のアニオンがトリメチルシリル基のプ

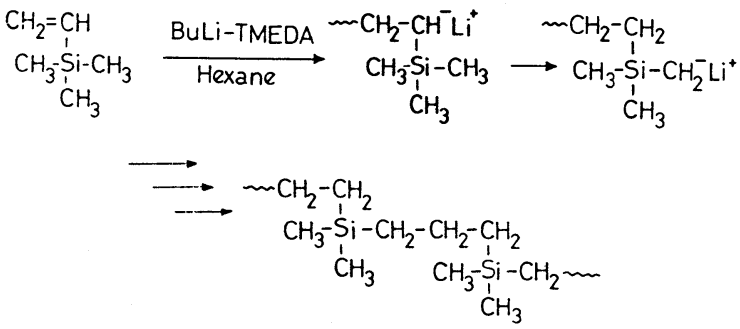

ロトンを分子内で引き抜きながら生長を続ける異性化重 合が起こることを見出している30)。その機構の解明によ りケイ素置換 $\alpha$-炭素アニオンの安定性と活性について より深い知見が得られることが期待される。桜井らは不 安定なジシレンの等価体として 16 を用い, テトラヒド ロフラン中, $-78^{\circ} \mathrm{C}$, メルリチウムにより重合を行い 分子量分布の狭いポリシランを得ている311。この研究の 進展はレジスト材料としての応用に限らず，ヶイ素アニ オンの化学として極めて興味深いものである。

\section{3. ブロック共重合体}

アニオンリビング重合の特長については，本文を通じ 何度か触れてきたが，ここでもう一度整理してみると以 下の 3 点に集約できる。

1）分子量の制御が可能であること。

2）分子量分布の狭い, 分子量の良く揃ったポリマー が合成できること。

3）ブロック共重合体の合成ができること。

最初のモノマーよりリビングポリマーが得られ，その 生長鎖末端が安定ならば, 第 2 のノマーを加えること によりブロック共重合体が得られる。特に第 2 のモノ マーの重合もリビング的に進行すれば，得られるブロッ ク共重合体の組成は, 最初と第 2 のモアーの仕込みモ ル数で決まり，1）と2)の特長を合わせもつため理想的 な合成法になる。

ブロック共重合体は一般にブロック鎖同志が混ざり合 い難いことより，それぞれのブロック鎖の長さやモ， マー単位の性質，その他の条件により，図 3,4に模式的 に示すように分子レベルで様々なパターンの相分離(ミ クロ相分離)を起こす。このミクロ相は $10 \sim 10^{3} \AA$ の大 きさを持ち，相の界面をポリマー鎖が横断していること などから，他の共重合体や単独重合体では見られない独 特の物性が現われ興味深い。

前章で 1 12のモノマーのアニオンリビング重合と得 られたポリマーについて，主に1)と2)の特長について 述べてきた。リビング重合の利点である 3)について少 し詳しく述べてみる。

1３, 5７より生成するリビングポリマーは, 反応 性の高いシリル基を有しているが条件を選べば長時間安

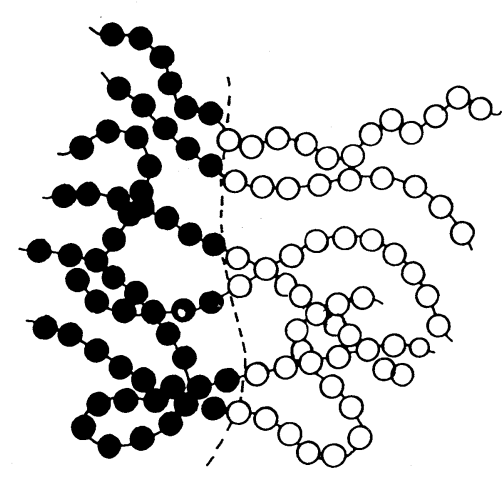

Fig. 3 Schematic representation of microphase separation of a block copolymer. -00- B-block 


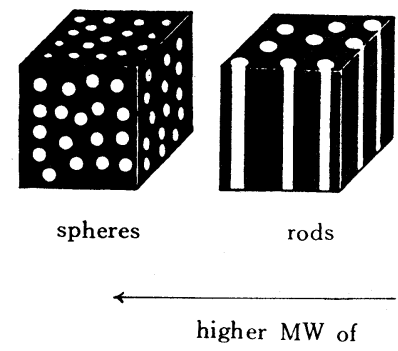

A block

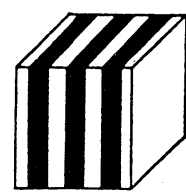

lamellae

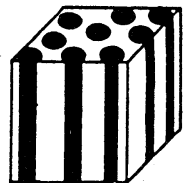

rods

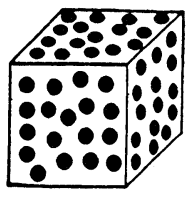

spheres

Fig. 4 Schematic representation of morphological forms in block copolymers.

定に存在する。末端アニオンはリビングポリスチレン同 様高い求核性を保持しており，スチレンやイソプレンを 重合する能力があり，実際にそれらとブロック共重合体 を定量的に与える。逆にスチレンやイソプレンのリビン グポリマーにこれらのモノマーを加えても同様に，構造 やブロック鎖長の規制されたブロック共重合体が得られ る。8については生成するリビングポリマーの安定性に やや問題があり，これにスチレンを加えるとブロック共 重合体とともに 8 の単独重合体も一部混入する。リビン グポリスチレンに 8 を加えると予想通りの組成, 鎖長を 持つブロック共重合体が生成することよりモノマーの加 える順序が大事である。

9のリビングポリマーに $\alpha$-メチルスチレンを加える とブロック共重合体が得られる。10１2についてはブ ロック共重合が記述されていないが，9の成功を考えれ ば，恐らく問題なく条件さえ選べば進行すると推測でき る。

それに対して本文で述べた唯一のジエンモノマー4で は状況が異なる。リビングポリスチレンはイソプレンを 重合する能力があり, 一方リビングポリイソプレンから もスチレンは重合が可能であり，共に予想通りのブロッ ク共重合体が得られる。このことより重合に関する限り, 両者のリビングポリマーの末端アニオンの反応性は同等 とされている。4より生成したリビングポリマーに4を 加えると重合は起き分子量が増加するのに対し，イソプ レンを加えてもその重合は開始されず，4の単独重合体 が回収されるだけである。従って 4 のリビングポリマー の活性末端カルバニオンはその反応性が著しく低下して いるようである。逆にリビングポリスチレンやリビング ポリイソプレンに 4 を加えると重合は順調に進行し, 加 えたモル数に応じた設計通りのブロック共重合体の合成 が可能であった。

以上 4 と 8 はリビングポリマーの反応性や安定性を考 慮し, モノマーを加える順序に注意が必要であるが, 少
なくとも 1〜3，5７，9に関してはリビング重合の利点 を生かし，スチレンやジエン類とのブロック共重合体の 合成ができる。共重合の組み合わせも，ここで述べたモ ノマーの間でも反応性を考えれば当然可能と思われ，ま た合成されたものや可能性を含めいずれも全く新しい夕 イプのブロック共重合体であることより，それらの特異 な機能や性質が大いに期待できる。

\section{4. おわりに}

シリル基を含むスチレンおよびブタジエン誘導体のリ ビングアニオン重合について，最近我々が得た研究成果 を中心に述べてきた。ここで示した以外にも反応性シリ ル基は多数あり，これらの基と炭素アニオンの共存でき る条件を追究することにより，また新しいリビングポリ マーを作り出すことが期待される。そのリビングポリ マーはそれぞれのブロック共重合体を導き, 反応性シリ ル基による高分子反応によってらさに新しい材料へと誘 導できるであろう。いずれにしてもリビング重合が根本 にあるため，分子設計を考える上で好都合と思われる。

本文で述べたアニオンリビング重合では, 試薬類はす べて厳密に精製・乾燥する必要がある。また末端アニオ ンの反応性を考えると不活性ガス雲囲気下か高真空下の 条件も要求されるなど煩雑な操作を避けることはできな い。しかし工場レベルで生産されるモノマー類が想像以 上に精製され純度が高く，実際に小規模なスケールでは アニオンリビング重合が行われていることを考えれば, ポリマーの用途が開発され, その要求が高まれば実用化 はそれほど困難ではないように思われる。

(昭和 63 年 12 月 30 日受理)

\section{文 献}

1) M. Szwarc, Nature, 178, 1169 (1956)

2) ビニルモノマーに限ってみると，スチレンや共役 ジエン類以外にもビニルピリジンやメチルメタク 
リレートのリビングポリマーが報告されており， 分子量分布の狭いポリマーやブロック共重合体も 合成されている。しかし活性末端の長時間にわた る安定性や停止反応について爰密に考えるとやや 問題が残る。

3）鶴田禎二，高分子の合成 [I]（化学増刊） p.54 (1961)

4）相田卓三，井上祥平，有合化，43，300（1985）

5) O.W.Webster, W.R. Hertler, D.Y. Sogah, W.B. Harnham, T.V. RajanBabu, J. Am. Chem. Soc., 105, 5706 (1983)

6) 大津隆行, 大屋尚洋, 化学, 38, 142 (1983)

7）東村敏延，高分子，35，112 (1986)

8) Y. Doi, T. Keii, Adv. Polym. Sci, 73/74, 201 (1986)

9) L.R. Gilliom, R.H. Grubbs, J. Am. Chem. Soc., 108, 733 (1986)

10）藤本輝雄，新実験化学講座，19, 高分子化学 [I] p.185 (1978)

11) A. Hirao, S. Nakahama, Macromolecules, 20, 2968 (1987) ; A. Hirao, Y. Ishino, S. Nakahama, ibid., 21,561 (1988)

12）中浜精一, 平尾 明, 有合化, 44, 137 (1986)

13）熊田誠, 角村真一, 谷村正満, 小谷 壽, 石川満夫, 玉村敏昭，岡村清人，高分子，37，447（1988）

14) A. Hirao, T. Nagawa, T. Hatayama, K. Yamaguchi, S. Nakahama, Macromolecules, 18, 2101 (1985)

15) A. Hirao, T. Hatayama, T. Nagawa, M. Yama guchi, K. Yamaguchi, S. Nakahama, ibid, 20, 242 (1987)

16）ここでは全てのモノマーを便宜上，スチレン誘導 体として命名した。Chem. Abst., では, 4Ethenylbenzene 誘導体として扱われている。

17) E.J. Corey, A. Venkatesworlu, J. Am. Chem.
Soc., 94, $6190(1972)$

18) A. Hirao, K. Kakenaka, S. Packirisamy, K. Yamaguchi, S. Nakahama, Makromol. Chem., 186, 1157 (1985)

19) K. Takenaka, A. Hirao, T. Hattori, S. Nakahama, Macromolecules, 20, 2034 (1987)

20) K. Takenaka, A. Hirao, S. Nakahama, ibid., (1989) in press

21) F. Sato, H. Uchiyama, A.K. Samaddar, Chem. Ind ., 1984, 743

22) Y.X. Ding, W.P. Weber, Macromolecules, 21, 530 (1988)

23) N. Yamazaki, S. Nakahama, A. Hirao, Y. Shiraishi, H.M. Phung, Contemp. Top. Polym. Sci., 4, 379 (1984)

24) P. Chaumont, G. Beinert, J.E. Herz, P. Rempp, Makromol. Chem., 183, 1181 (1982)

25) A. Hirao, T. Hatayama, S. Nakahama, Macromolecules, 20, 1505 (1987)

26) T. Taki, A. Hirao, S. Nakahama, Polym . Preprints, $J p n, 39,(1989)$ in press

27) K. Saigo, F. Watanabe, J. Polym. Sci., Polym. Chem. Ed., (1989) in press

28) M. Matsumura, T. Kazama, K. Se, T. Fujimoto, Polym. Preprints, Jpn., 33, 153 (1984)

29) K. Hatada, K. Ute, K. Tanaka, Y. Okamoto, T. Kitayama, Polym. J., 18, 1037 (1986) ; A.H.E. Müller, L. Lochmann, J. Trekoval, Makromol. Chem., 186, 1473 (1986)

30) R. Asami, J. Oku, M. Takeuchi, K. Nakamura, M. Takaki, Polym.J., 20, 699 (1988)

31）小畠邦規, 平田寛樹, 山口宗宏, 坂本健吉, 櫻 井英樹, 日本化学会第 56 回春季年会予稿集 I p.504 (1988) 